\title{
TINGKAT KEKERASAN PERMUKAAN RESIN KOMPOSIT AKIBAT MASA KEDALUWARSA MATERIAL
}

Yuvika Intan Ristian Putri ${ }^{\star}$, Muhammad Dian Firdausy ${ }^{* *}$, Niluh Ringga Woroprobosari ${ }^{\star * *}$

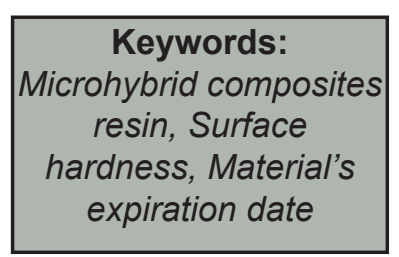

\section{ABSTRACT}

Background: Aplication of composites resin in relatively small amount as a restorative material often causing the material reaches its expiry date before all of the material can be used. Composites resin that have passed the expiry date would affect charateristic of the material. The aim of this study was to investigate surface hardness difference of composite resins based on material expiration date.

Methods: This research was an experimental laboratory using post test only with control group design. Samples for this research were 27 divided into 3 groups based on its expiration date (2016, 2018 and 2019). The surface hardness was measured by Shore D Hardness. The result of this research were tested with One Way Anova and Post Hoc test LSD.

Result: The lowest surface hardness result was measured on group 1 (81.02 SHD) and the highest was group 3 (94.72 SHD). The result of One Way Anova test showed that there was significant differences in all groups $(p<0.05)$. Post Hoc LSD test showed difference significantly between each groups.

Conclusion: It can be concluded that there was significant difference of composite resins surface hardness based on material's expiration date.

\section{PENDAHULUAN}

Karies gigi merupakan penyakit jaringan keras gigi yang disebabkan oleh aktivitas metabolisme bakteri dalam plak yang menyebabkan demineralisasi akibat interaksi antara produk mikroorganisme, saliva dan substrat ${ }^{1}$. Perawatan karies gigi dapat dilakukan dengan cara penumpatan yang merupakan tindakan perawatan dengan memberi bahan tumpatan pada karies gigi yang sudah dibersihkan².

Bahan tumpatan yang sering digunakan dalam kedokteran gigi salah satunya adalah resin komposit ${ }^{1}$. Resin komposit tersusun dari 3 komponen utama yaitu matriks resin, bahan pengisi (filler) dan coupling agent. Komponen lain dalam resin komposit yaitu bahan penghambat polimerisasi (untuk membatasi terjadinya proses polimerisasi selama penyinaran), bahan pemula polimerisasi (initiator), bahan aktif polimerisasi (activator) dan modifier optic ${ }^{3}$.

Nilai estetik yang baik merupakan alasan resin komposit banyak digunakan di kalangan masyarakat karena warna yang mirip dengan gigi asli. Sifatnya yang tidak mudah larut, penghantar panas yang rendah dan mudah untuk dimanipulasi juga terdapat pada resin komposit ${ }^{2}$. Sifat lain yang dimiliki resin komposit sebagai bahan restorasi adalah kekerasan permukaan. Kekerasan permukaan digunakan sebagai alat ukur untuk mengetahui kemampuan suatu bahan dalam menahan daya tekanan ${ }^{4}$. Kekerasan permukaan yang rendah pada bahan akan mengakibatkan bahan tersebut lebih mudah tergores ${ }^{3}$.

Penggunaan resin komposit yang relatif

*Program Pendidikan Dokter Gigi Fakultas Kedokteran Gigi Universitas Islam Sultan Agung Semarang,

${ }^{* *}$ Departemen Dental Material Fakultas Kedokteran Gigi Universitas Islam Sultan Agung Semarang, ${ }^{* * * D e p a r t e m e n}$ Radiologi Forensik Fakultas Kedokteran Gigi Universitas Islam Sultan Agung Semarang Korespondensi: yuvika.intan77@gmail.com 
sedikit pada permukaan gigi membuat resin komposit tersimpan terlalu lama hingga mencapai kedaluwarsa sebelum semua material habis digunakan sehingga tidak diketahui apakah bahan material yang sudah kedaluwarsa masih mempertahankan sifat material dengan baik atau akan mempengaruhi sifat material di dalamnya ${ }^{5}$. Terkadang pada praktik dokter gigi, saat bahan material habis dan diperlukan secara mendesak, dokter gigi terpaksa menggunakan resin komposit yang sudah tersimpan lama tanpa mengetahui konsekuensi penggunaanya ${ }^{6}$.

Tujuan penelitian ini adalah untuk mengetahui perbedaan tingkat kekerasan permukaan resin komposit akibat masa kedaluwarsa material sehingga diharapkan penelitian ini dapat menjadi informasi di bidang restorasi mengenai perbedaan tingkat kekerasan permukaan resin komposit akibat masa kedaluwarsa, dapat menambah pengetahuan mengenai kualitas material tumpatan bagi peneliti maupun klinisi, dan mengetahui penurunan kualitas yang dilihat dari kekerasan permukaan material yang sudah kedaluwarsa sebagai prinsip beneficience memberikan pelayanan terbaik untuk pasien. Hipotesis penelitian ini adalah terdapat perbedaan tingkat kekerasan permukaan resin komposit akibat masa kedaluwarsa material.

\section{METODE PENELITIAN}

Penelitian ini dilaksanakan di Laboratorium Fakultas Kedokteran Gigi UNISSULA Semarang. Jenis penelitian adalah penelitian eksperimental laboratoris secara in vitro dengan rancangan post test only control group. Sampel yang digunakan adalah resin komposit microhybrid (FiltexTM Z250 shade A2 (3M)) dengan jumlah sampel 27 buah dibagi dalam 3 kelompok. Pada kelompok 1 adalah sampel resin komposit microhybrid dengan kedaluwarsa tahun 2016, kelompok 2 adalah resin komposit microhybrid dengan kedaluwarsa tahun 2018, dan kelompok 3 adalah resin komposit microhybrid dengan kedaluwarsa tahun 2019.

Sampel dicetak dengan cetakan stainless steel dengan diameter $8 \mathrm{~mm}$ dan ketebalan $2 \mathrm{~mm}$. Penyinaran resin komposit dengan menggunakan light curing unit (Woodpecker LED-B) selama 20 detik dengan arah tegak lurus dan jarak $0,1 \mathrm{~mm}$. Setelah setting sampel resin komposit dilepaskan dari cetakan dan tepi sampel yang kasar di haluskan dengan menggunakan amplas. Sampel disimpan selama 24 jam dalam plastik berperekat secara terpisah berdasarkan kelompoknya di laboratorium FKG Unissula dalam suhu ruangan.

Pengukuran kekerasan dengan menggunakan alat Shore D Hardness Tester. Sampel diletakan pada permukaan yang rata dan keras, kemudian nyalakan alat Shore D Hardness Tester dan diletakan di atas permukaan sampel secara tegak lurus. Tekan alat sampel hingga jarum indenter masuk dan mengeluarkan hasil pengukuran. Pengukuran dilakukan sebanyak tiga kali pada setiap sampel pada tiga titik yang sudah ditandai kemudian dihitung nilai rata-ratanya. Catat hasil pengukuran kekerasan permukaan yang selanjutnya akan analisa data.

Analisis hasil penelitian ini menggunakan SPSS, dilakukan uji normalitas menggunakan Shapiro-wilk dan uji homogenitas dengan menggunakan uji Levene statistic. Setelah data yang didapat terdistribusi normal dan homogen maka dilanjutkan dengan analisa uji One Way ANOVA dan uji Post Hoc Test yaitu LSD Multi Comparison. 
HASIL

Hasil pengukuran kekerasan permukaan pada tiga kelompok sampel resin komposit microhybrid sebagai berikut :

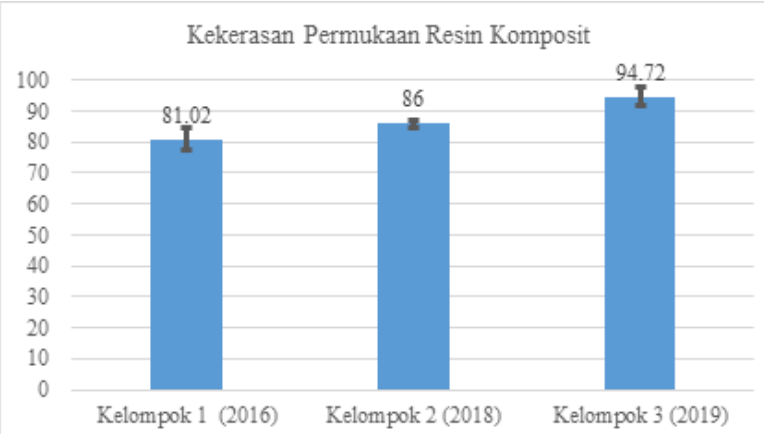

Gambar 1. Kekerasan Permukaan Resin Komposit

Pada grafik di atas dapat disimpulkan bahwa rata-rata nilai kekerasan permukaan pada kelompok 1 sebesar 81,022 SHD, kelompok 2 sebesar 86,000 SHD, dan pada kelompok 3 sebesar 94,722 SHD (gambar 1). Setelah dilakukan uji normalitas dan homogenitas didapatkan data yang normal dan homogen untuk selanjutnya dilakukan uji One Way Anova. Hasil uji One Way Anova menunjukkan adanya perbedaan yang signifikan dari hasil rata-rata ketiga kelompok dengan $p$ value $<0,05$.

Tabel 1. Hasil Uji Post Hoc LSD

\begin{tabular}{cccc}
\hline \multicolumn{2}{c}{ Kelompok } & Sig & Ket \\
\hline Kelompok 1 & Kelompok 2 & 0.001 & $\begin{array}{c}\text { Berbeda } \\
\text { bermakna }\end{array}$ \\
\cline { 2 - 4 } & Kelompok 3 & 0.000 & $\begin{array}{c}\text { Berbeda } \\
\text { bermakna }\end{array}$ \\
\hline Kelompok 2 & Kelompok 1 & 0.001 & $\begin{array}{c}\text { Berbeda } \\
\text { bermakna }\end{array}$ \\
\cline { 2 - 4 } & Kelompok 3 & 0.000 & $\begin{array}{c}\text { Berbeda } \\
\text { bermakna }\end{array}$ \\
\hline Kelompok 3 & Kelompok 1 & 0.000 & $\begin{array}{c}\text { Berbeda } \\
\text { bermakna }\end{array}$ \\
\cline { 2 - 4 } & Kelompok 2 & 0.000 & $\begin{array}{c}\text { Berbeda } \\
\text { bermakna }\end{array}$ \\
\hline
\end{tabular}

Berdasarkan hasil uji Post Hoc LSD diperoleh nilai $p$ value $<0.05$ pada perbandingan masing-masing kelompok bahwa terdapat perbedaan kekerasan permukaan yang signifikan pada resin komposit berdasarkan masa kedaluwarsanya (lih. tabel 1).

\section{DISKUSI}

Hasil pengukuran kekerasan permukaan pada tiap kelompok bahwa kekerasan terendah terdapat pada kelompok 1 dengan masa kedaluwarsa tahun 2016 dan kekerasan permukaan tertinggi terdapat pada kelompok 3 dengan masa kedaluwarsa tahun 2019. Semakin mendekati atau bahkan melewati masa kedaluwarsa, semakin menurun pula tingkat kekerasan permukaan resin komposit. Hal tersebut menunjukkan masa kedaluwarsa material mempengaruhi hasil kekerasan permukaan resin komposit. Bahan material yang mendekati atau sudah melewati masa kedaluwarsa mengalami penurunan aktifitas pada komponen penyusunnya berupa partikel bahan pengisi (filler) dalam resin seiring dengan shelf life yang dibatasi oleh masa kedaluwarsa ${ }^{6}$. Seiring dengan masa simpan bahan (shelf life) yang sudah berakhir, proses polimerisasi tidak sempurna karena photoinisiator yang sudah mengalami penurunan selama masa penyimpanan ${ }^{8}$.

Sumber cahaya akan mengeluarkan foton untuk mengaktivasi photoinisiator untuk memulai polimerisasi. Jumlah photoinisiator yang teraktivasi tergantung pada konsentrasi photoinisiator dalam material dan energi foton ${ }^{7}$. Champoroquinone yang terkandung dalam photoinisiator 
diaktifkan dengan bantuan sumber cahaya sehingga menghasilkan sifat mekanik resin komposit ${ }^{3}$. Photoinisiator yang sudah mengalami penurunan lalu diaktifkan dengan sinar maka terjadi penguraian rantai ganda, menghasilkan radikal bebas dan membentuk monomer sisa sehingga polimerisasi tidak memadai ${ }^{5}$. Polimerisasi yang tidak memadai akan menyebabkan sifat fisik dan mekanik yang dihasilkan resin komposit tersebut tidak akan maksimal. Termasuk tingkat kekerasan permukaan, dimana polimerisasi yang tidak merata akan menurunkan kekerasan permukaan yang mengakibatkan keausan pada resin komposit.

Polimerisasi yang tidak optimal selain mempengaruhi tingkat kekerasan permukaan juga mengalami perubahan pada kekerasan mikro dan kekasaran pemukaan ${ }^{5}$. Akibat Resin komposit yang sudah melewati kedaluwarsa juga menghasilkan pengurangan radiopasitas serta ketahanan mekanis dari material, karena pelepasan ion yang dapat mematahkan ikatan kimia antara partikel pengisi dan matriks ${ }^{8}$. Terjadi Penurunan kekuatan perlekatan dan kebocoran microleakage pada resin komposit ${ }^{6}$.

Oleh karena itu dapat disimpulkan terjadi penurunan kekerasan permukaan pada resin komposit yang sudah mengalami kedaluwarsa dibanding dengan resin komposit yang belum kedaluwarsa. Penurunan sifat mekanik tersebut seiring dengan menurunnya bahan pengisi (filler) resin komposit karena shelf life pada bahan material resin komposit yang kedaluwarsa. Tidak disarankan penggunaan restorasi dengan bahan resin komposit yang sudah kedaluwarsa karena sudah mengalami penurunan kualitas material.

\section{KESIMPULAN}

dilakukan, maka dapat disimpulkan bahwa terdapat perbedaan kekerasan permukaan resin komposit microhybrid akibat masa kedaluwarsa. Penurunan sifat mekanik tersebut seiring dengan menurunnya bahan pengisi (filler) resin komposit karena shelf life pada bahan material resin komposit yang kedaluwarsa. Penelitian selanjutnya dapat dilakukan penelitian dengan melihat sifat mekanik dan sifat fisik maupun klinis pada resin komposit yang sudah melewati masa kedaluwarsa.

\section{DAFTAR PUSTAKA}

1. Tulenan, D.M.P., Wicaksono, D.A. \& Ratulangi, U.S. 2014. Gambaran Tumpatan Resin Komposit Pada Gigi Permanen Di Poliklinik Gigi Rumkital Dr.Wahyu Slamet. J e-GiGi (eG). 2(2).

2. Anang, D.Y., Mariati, N.W. \& Mintjelungan, C.N., 2015. Penggunaan Bahan Tumpatan Di Rumah Sakit Gigi Dan Mulut Pspdg Fakultas Kedokteran Unsrat Pada Tahun 2014. J e-GiGi (eG). 3:3-6.

3. Anusavice, PhD, K.J., Rawls, PhD, R. \& Shen, PhD, C., 2013. Phillip'S Science of Dental Materials. ed ke-12. Missouri: Elsevier, pp. 277304

4. Sitanggang, P., Tambunan, E., Wuisan, J. 2015. Uji Kekerasan Komposit Terhadap Rendaman Buah Jeruk Nipis (Citrus Aurantifolia). J e-GiGi (eG). 3:229-234.

5. Garcia, L. da F.R., Rego Roselino, L. de M. \& Pires de Souza, Fernanda de Carvalho Panzeri Consani, S. 2010. Evaluation Of The Conversion Degree, Microhardness, And Surface Roughness Of Composite Resins Used After Their Expiration Date. www.agd.org, pp.262-267.[19 April 2017].

6. Talreja, N., Shilpy, S., ND, S. 2017. Comparative Evaluation of Bond Strength and Microleakage of Standard and Expired Composite at Resin - Dentin Interface: An in vitro Study. IJCPD. 10(1):1-4.

7. Pasril, Y., Pratama, W.A. 2013. Perbandingan Kekuatan Tekan Resin Komposit Hybrid Menggunakan Sinar Halogen Dan LED Comparison of Compressive Strength Hybrid Composite Resin Using Halogen and LED Light. IDJ. 2(2):83-90.

8. Tirapelli,C., Carvalho,F., Panzeri,H. 2004. Radiopacity and Microhardness Changes and Effect of X-ray Operating Voltage in Resin-Based Materials before and after the Expiration date. www.scielo.br. pp. 409-412.[1 Februari 2018]

Berdasarkan penelitian yang telah 